\title{
LesBiGay Identity as Commodity
}

\author{
David M. Skover \& Kellye Y. Testy $\dagger$
}

This Essay explores the deep dissonance that exists today between the validation of American LesBiGays in the commercial marketplace and their devaluation in political and legal arenas, and questions the failure of legal scholars and civil rights activists to account meaningfully for this dissonance in their theories and practices.

In America's popular culture, LesBiGay identities abound. In its political culture, however, they emerge more tentatively. The commercial and entertainment industries increasingly commodify and celebrate LesBiGay identities. The courts and legislatures generally discount and condemn them. Thus, there is a deep dissonance between the validation of LesBiGay identities in the economic marketplace of items and ideas, and their devaluation in the legal arena of rights and remedies. Such a dissonance fosters a fragmented sense of what LesBiGay identities are, and whether or how they are valued.

Surprisingly, this schizoid treatment of LesBiGay identity is largely ignored or misunderstood by legal theorists and practitioners. Typically, they look primarily to politics and law for the paths to LesBiGay selfrealization and social inclusion. The academy and activists have yet to appreciate that consumer-driven corporatism, commercial entrepreneurship, and the fetishes and fantasies of the mass media are unleashing powerful cultural forces that will influence, for better or worse, the LesBiGay quest for liberty and equality. For if "the business of America is business," then surely the Americanization of the LesBiGay identity is business, too.

Copyright $\odot 2002$ David M. Skover and Kellye Y. Testy.

$\dagger$ David Skover and Kellye Testy are friends and professorial colleagues at Seattle University School of Law. They dedicate this Essay to the memory of their dear friend, Professor Rebecca S. Rudnick, who would have been attuned to their perspectives on commodification. They are grateful for the thoughtful, and sonetimes even critical, comments of Janet Ainsworth, Ronald Collins, Colin Folawn, Carmen Gonzalez, Sean Patrick O'Reilly, Julie Shapiro, and Tracey Thonıson. They thank, as well, Martha Ertman, Adrienne Davis, and Joan Williams, and the other participants in the University of Denver and Ainerican University's conference, Commodification Futures, where this Essay was presented as a work in progress. Finally, they appreciate the unstinting support of Dean Rudy Hasl of the Seattle University School of Law and of their administrative assistant, Nancy Ammons. 
Consequently, any legal theory or political program that takes no serious account of the commodified LesBiGay identity is likely to fail. Such a serious account is the object of this essay.

\section{INTRODUCTION \\ COMMERCE "OUTS" IDENTITY}

No matter their size, shape, shade, or sex, people, like products, are given personalities in the American commercial marketplace. In most lifestyle choices-such as clothes worn, cars driven, jobs worked, foods eaten, pets pampered, films seen, magazines read, programs watched, or music heard-Americans order the personalities that they both want and can afford to project from the menu that commerce offers. Essentially, Americans consume their identities, a paradoxical form of self-definition through self-cannibalization. In the realm of commerce, no one can remain in the closet.

"LesBiGay"1 identity appears to be the specialty du jour for sale on commerce's cart. Having discovered LesBiGays as a significant market sector, capitalist vendors now endlessly pitch products to them. Moreover, these savvy vendors now pitch the LesBiGay identity itself as a product. $^{2}$

1. The term "LesBiGay," in some real senses, is unfortunate. First, it does not comprehend all individuals who are the victims of discrimination due to sexual identity, such as transsexuals and transgendered persons, or those who prefer other monikers, such as "queer." Second, the term lumps together three sexual minority groups that are not necessarily situated in identical socioeconomic and political contexts. Nevertheless, as our Essay demonstrates, it is LesBiGay folk (or, perhaps more accurately, a segment of them) who have become the newest heirs to America's commercial largesse.

2. America has neither commodified all LesBiGay identities to the same extent, appealed to all LesBiGay consumers to the same degree, nor enriched all LesBiGay lifestyles by the same amount. Quite obviously, the LesBiGay cultural identity that pervades most commercial media and markets is largely a Caucasian, upper-class, youthful, and able-bodied one. Thus, some critics of LesBiGay commodification argue that the American commercial culture maintains, if not widens, socioeconomic and political gaps. For example, in a Millennium March reading, the African-American gay activist Keith Boykin declared:

I speak to resist the commercialization and commodification of a mainstream Gay lifestyle that enriches a privileged few and impoverishes the masses with a bankrupt culture of uniformity... I speak so that my silence will not be interpreted as complicity, my concerns not discarded dismissively, and my thoughts not represented simplistically.

See Michael C. Bradbury, Millennium March Inspires GLBT Community and Allies, SEATTLE GaY NEws ONLINE, May 5, 2000, at http://www.sgn.org/archives/sgu.5.5.00/ (last visited Oct. 28, 2001).

Respected scholars have addressed the marginalization of LesBiGays of color in law's narrow construct of LesBiGay identity. See, e.g., Devon W. Carbado, Black Rights, Gay Rights, Civil Rights, 47 UCLA L. Rev. 1467 (2000); Darren Lenard Hutchinson, "Gay Rights" for "Gay Whites"?: Race, Sexual Identity, and Equal Protection Discourse, 85 CoRNeli L. Rev. 1358 (2000); Darren Lenard Hutchinson, Out Yet Unseen: A Racial Critique of Gay and Lesbian Legal Theory and Political Discourse, 29 ConN. L. Rev. 561 (1997). Extrapolating from their theses, commodification appears to yield economic benefits only for LesBiGays who fit mass commercial images, and affix or affirm race, class, and gender divisions among LesBiGays.

Although the readers of this Essay ought to remain ever conscious of such critical issues, their attention is directed to the recent fiourishing of any LesBiGays in commercial coding. The actual workings of America's commercial culture, its popularization of LesBiGay imagery, and the 
LesBiGay images infuse commodities with illusions of chic and trendy lifestyles ready-made to buy. Sean Strub, a New York marketer, colorfully captures the inextricable link between his gay identity and his commercial choices: "I buy my Christmas gifts from the Shocking Gray catalogue, I wash my hair with Pride shampoo, I wear Don't Panic T-shirts, and I stamp 'Gay Money' on my cash."3

Although American commerce capitalizes on LesBiGays as consumers, American politics and law exploit LesBiGays as citizens. Whether in the chambers of the judiciary, on the floors of the legislatures, at the ballot boxes of the electorate, or through the ranks of the military, the state demands that LesBiGays fulfill their civic responsibilities, but it denies their civil rights. With statutory and common-law "crimes against nature," the Defense of Marriage Act, "special rights,"6 and policies such as "don't ask, don't tell,"7 the state forces LesBiGays to yield to its discriminatory

ramifications of the commodified LesBiGay identity for law are this Essay's immediate concerns. The distributional critiques of Hutchinson, Carbado, and others must be the focus of future legal writers who become fully conscious of the ineluctable link betwcen commerce and LesBiGay sexuality.

3. David J. Jefferson, Businesses Offering Products for Gays Are Thriving: Rise in Activism and Public Acceptance of Lifestyles Increase Demand, WaLL Sr. J., Apr. 22, 1993, at B2 (quotimg Sean Strub, president of Strubco, Inc., a marketing agency in New York that targets LesBiGay consumers). The companies and products mentioned by Mr. Strub are either LesBiGay-owned and operated or LesBiGay-oriented.

4. At America's founding, all thirteen colonies either had specific statutes outlawing sodomy or had general statutory provisions incorporating the English common law, which was held to include the "crime against nature." See Bowers v. Hardwick, 478 U.S. 186, 194 n.5 (1986) (listing statutory provisions). Currently, sixteen states and Puerto Rico have sodomy laws on the books that have not clearly been invalidated by the courts. See ACLU-Lesbian \& Gay Rights, "Crime" and Punishment in America, at http://www.aclu.org/issues/gay/sodomy.html (last visited Sept. 6, 2001). The statutes differ in the severity of their punishment. For example, Idaho provides a minimum sentence of five years for whomever "is guilty of the infamous crime against nature, committed with mankind or with any animal." IDAHo CODE $\$ 18-6605$ (Michie 1998). In contrast, Texas punishes "deviate sexual intercourse with another individual of the same sex" as a Class C misdemeanor with a maximum penalty of a $\$ 500$ fine. TEX. PENAL CODE ANN. $\$ 21.06,12.23$ (Vernon 1998). As late as 1972, Florida's jails held eighty-five convicts imprisoned for "crimes against nature." See Hastings Wyman, Homosexuality and the High Court, WASH. POST, June 11, 2001, at C5.

5. Pub. L. No. 104-199, 110 Stat. 2419 (1990) (providing that fcderal laws cannot be construed to include same-sex couples as spouses).

6. "Stop special class status for homosexuality" and "Special rights for hounosexuals just isn't fair" were two of the slogans that appeared in propaganda supporting passage of Colorado Amendment 2 , the state constitutional amendment denying protected status based on sexual orientation that was invalidated by the U.S. Supreme Court in Romer v. Evans, 517 U.S. 620 (1996). See LISA KeEN \& SuzanNe B. Goldberg, Strangers to the Law: Gay People on Trial 133-57 (1998).

7. National Defense Authorization Act of 1994, Pub. L. No. 103-160, $\$ 546$ (codified at 10 U.S.C. $\S 654$ (1993)). For the one year period ending September 30,2000 , the number of personnel leaving the U.S. military after voluntarily admitting to sexual mimority orientation jumped by $28 \%$, to a total number of 1,106. Fort Campbell, Kentucky, the military installation at which Pfc. Barry Winchell was beaten to death in July of 1999, experienced the largest number (161) of discharges. Anti-Gay bias "pervaded the base and drove gays to seek discharges," explained Dixon Osbome, director of the Servicemembers Legal Defense Network. See Roberto Suro, Military's Discharges of Gays Increase: Army Base Where Anti-Gay Murder Occurred Had Record Number of Departures, Wash. Post, June 2, 2001, at A20. 
will in many intimate matters of personal freedom. Today's politics and law keep the closet door from swinging wide open.

In America's popular culture, then, LesBiGay identities abound. In its political culture, however, they emerge more tentatively. The commercial and entertainment industries increasingly commodify and celebrate LesBiGay identities. The courts and legislatures generally discount and condemn them. Thus, there is a deep dissonance between the validation of LesBiGay identities in the economic marketplace of items and ideas and their devaluation in the legal arena of rights and remedies. Such a dissonance fosters cultural fragmentation of LesBiGay identities, and questions whether or how they are valued.

Surprisingly, legal theorists and practitioners have largely ignored or misunderstood this schizoid treatment of LesBiGay identity. Typically, they look primarily to politics and law for the paths to LcsBiGay selfrealization and social inclusion. The academy and activists have yet to appreciate that consumer-driven corporatism, commercial entrepreneurship, and the mass media's fetishes and fantasies are unleashing powerful cultural forces that will influence, for better or worse, the LesBiGay quest for liberty and equality. For if "the business of America is business," then surely the Americanization of the LesBiGay identity is business, too. Consequently, any legal theory or political program that takes no serious account of the commodified LesBiGay identity is likely to fail. Such a serious account is the object of this Essay.

\section{I \\ An Overview of THE Cultural Landscape}

\section{A. Political and Legal Losses}

Consider the past fifteen years. At the federal level, start with Bowers v. Hardwick, ${ }^{9}$ proceed through a decade of judicial resistance to equal protection claims, ${ }^{10}$ move on to the political and military brouhaha surrounding "don't ask, don't tell," "11 and culminate with Congress's unambiguous statement of disrespect in the Defense of Marriage Act ("DOMA"). ${ }^{12}$ At the state level, the "no promo homo"13 creed that inspired so many statu-

8. This celebrated phrase was first uttered by President Calvin Coolidge in his address to the Society of American Newspaper Editors on January 17, 1925. JoHN BARTLETT, Familiar Quotations 859 (13th ed. 1955).

9. 478 U.S. 186 (1986) (denying a substantive due process right to privacy in homosexual consensual sodomy).

10. See, e.g., Ben Shalom v. Marsh, 881 F.2d 454 (7th Cir. 1989) (denying lesbians suspect class status); Padula v. Webster, 822 F.2d 97 (D.C. Cir. 1987) (holding that discrimination against homosexual conduct, as opposed to status, does not violate equal protection).

11. National Defense Authorization Act, supra note 7.

12. Pub. L. No. 104-199, supra note 5.

13. Although the origin of "no promo homo" is uncertain, the phrase first appeared in a major U.S. newspaper article reporting on a Virginia school system's pledge not to promote LesBiGay student 
tory prohibitions and constitutional initiatives in the $1990 \mathrm{~s}^{14}$ held its power into the new millennium. LesBiGay rights lost ground in state ballot initiative campaigns in the 2000 elections. Nebraska and Nevada slammed gay marriage by whopping majorities. Maine dug in its heels against legal protection for LesBiGays in housing, employment, and other civil rights. And even Vermont, hailed the year before as a pioneer in the recognition of civil union status for LesBiGay couples, jerked the reins of power from the state House Deinocrats who had passed the controversial bill, and nearly overthrew the governor who had signed it. ${ }^{15}$

In a real sense, all of this is inevitable. A confluence of forces makes it unlikely that LesBiGays will wield any effective power in the majoritarian politics of America's democratic republic. Even if LesBiGays are as numerous as the most optimistic estimates would have it, ${ }^{16}$ their geographic dispersion, with the exception of a few major cities, dilutes their potential political power. Moreover, the fragile ties that inight bind LesBiGays together im single-issue politics are easily fractured by voter affiliation with other competing interests, including economic, gender, racial, or religious

activity. See Dan Beyers, Montgomery Students Push for Discussion of Gay Issues, WASH. Post, Dec. 8,1966 , at B1 (quoting Lawrence S. Jacobs, co-chairman of the Coalition to End Prejudice in Our Schools, who attributed the Montgomery County School Board's actions to what he called the county's "No Promo Homo" policy).

14. See, e.g., ConN. Gen. STAT. \$46a-81r (2)-(3) (1991) (forbidding promotion of homosexuality in education); MINN. STAT. \$363.021 (2)-(3) (1993) (same); Romer v. Evans, 517 U.S. 620 (1996) (mvalidating Amendment 2, added to the Colorado state constitution by referendum iu 1992 , that denied protected status based on sexual orientation).

15. Carey Goldberg, The 2000 Elections: The Ballot Initiatives, N.Y. TIMEs, Nov, 9, 2000, at B10. After the bitter election campaigns, the war over civil unions has continued to escalate within and outside of Vermont. Conservative Texas legislators aim to adopt a state law or constitutional amendment that forbids LesBiGay marriages or civil unions, and the Nevada proponents of the recently approved constitutional ban are encouraging other states to broaden their current laws to include domestic partnerships, civil unions, or other forms of LesBiGay relationships. On the other side of the trench, LesBiGay activists will propose bills to legalize same-sex civil unions in New York and Rhode Island, and the American Civil Liberties Union plans to undertake litigation to challenge the Nebraska constitutional amendinent. Peter LaBarbera, the president of Americans for Truth (a Washington, D.C. group opposing legal recognition of LesBiGay relationships), aptly characterized the intensity of the struggle: "This will be a long-term battle, like abortion. The people on our side are every bit as committed as the people on their side." David Crary, Same-Sex Unions Shaping up as Next Political Background: Vermont's Landmark Civil-Unions Law Has Inspired Many Same-Sex Couples to Tie the Knot, But It Also Has Galvanized Opposition to Gay Marriage, L.A. TIMEs, Jan. 28, 2001, at A1, A9. Currently, thirty-five states and the federal government have enacted "defense of marriage laws" that limit marriage to male-female unions. See Pamela Ferdinand, With Vermont in the Lead, Controversy Progresses; Battle over Same-Sex Unions Moves to Other States, WASH. Post, Sept. 4, 2001, at A3.

16. Bradley Johnson, What's Behind the Numbers, Advertising AGE, Jan. 18, 1993, at 35 (comparing Overlooked Opinions's 1990 estimate of nearly I8.5 million American homosexual adults, using the Kinsey Institute's estimate of LesBiGays as $10 \%$ of the American population in the 1940 s, to The Adrocate's more conservative 1993 estimate of 5 million White American homosexual adults). Of course, the speculative nature of such number-crunching is inevitable, given the dearth of more definitive data from U.S. Census questionnaires that fail to ask relevant questions regarding LesBiGay demographics. 
concerns. Energy available for single-issue measures is often squandered defending against anti-gay laws and ballot initiatives.

Thus, in order to win an election, a LesBiGay candidate or measure necessarily depends on the support of heterosexual voters. This may be improbable, given the overwhelming disaffection of the American people toward LesBiGays. As political scientist Kenneth Sherrill noted, "Only illegal aliens, who are neither citizens nor voters, rival lesbians and gay men ... [as the objects] of such sustained, extreme, and intense distaste."17 Additionally, the misperception that LesBiGays constitute a wealthy constituency able to buy political influence may discourage some heterosexual voters from sympathizing with the actual powerlessness that LesBiGays experience.$^{18}$ In fact, the widespread vetting of wildly exaggerated demographic information has provided fuel for the fires of social conservatives and the religious right, who have argued that well-heeled LesBiGays are surely in no need of "special rights,"19 a theme picked up by U.S. Supreme Court Justice Antonin Scalia in his stinging dissent in Romer v. Evans. ${ }^{20}$

Thus, it should come as no surprise that it is still legal in thirty-nine states to fire LesBiGays on account of their sexuality. ${ }^{21}$ It should come as no surprise that far fewer than one percent of all elected officials in

17. Kenneth Sherrill, The Political Power of Lesbians, Gays and Bisexuals, 29 P.S.: PoL. Sc1. \& PoL. 469,470 (1996).

18. Although some marketers portray LesBiGays as having disproportionately high income and education—such as the Simmons Market Research Bureau's 1988 report that placed the annual income of the average LesBiGay at $\$ 36,800$ (versus $\$ 12,287$ for the average heterosexual) and Overlooked Opinions's 1990 report that posited the number of LesBiGays with graduate degrees at $26 \%$ (versus $5 \%$ of the heterosexual population)--more reliable and realistic studies have found either that LesBiGay incomes are comparable to that of the population as a whole or, in fact, below that of heterosexuals with similar education and job experience. See, e.g., Dan Baker, A History in Ads: The Growth of the Gay and Lesbian Market, in Homo Economics: CAPITAlism, CoMmunity, and LesBian and Gay LiFE 12-13 (Amy Gluckman \& Betsy Reed eds., 1997) [hereinafter HoMo Economics] (discussing the "more scientific survey" of Yankelovich Partners in 1993 finding that LesBiGay incomes are comparable to the population as a whole); M.V. Lee Badgett, Thinking Homo/Economically, in A Queer World: The Center for Lesbian ANd Gay Studies Reader 470-71 (Martin Duberman ed., 1997) (citing a University of Chicago General Social Survey that found LesBiGay incomes to be lower than those of similarly situated heterosexuals).

19. See, e.g., Lisa Penaloza, We're Here, We're Queer, and We're Going Shopping! A Critical Perspective on the Accommodation of Gays and Lesbians in the U.S. Marketplace, in GAYS, LESBIANS, and Consumer Behavior: Theory, Practice, and Research Issues in Marketing 35-36 (Daniel L. Wardlow ed., 1996) (noting that in propaganda supporting Colorado's Amendment 2, the Coalition for Family Values cited the Simmons Market Research figures to argue that LesBiGays were not economically disadvantaged and needed no legal protection against discrimination).

20. 517 U.S. $620,645-46$ (1996) (Scalia, J., dissenting) ("[B]ecause those who engage in homosexual conduct tend to ... have high disposable income,... they possess political power much greater than their numbers, both locally and statewide.")

21. The Human Rights Campaign website tracks, inter alia, the states that ban private sector employment discrimination based on sexual orientation. Human Rights Campaign, Discrimination in the Workplace, at http://www.hrc.org/worknet/nd/states_ban_dso.asp (last visited Oct. 28, 2001). 
America are uncloseted LesBiGays. ${ }^{22}$ And it should come as no surprise that, even though a quarter of LesBiGays supported George W. Bush for President and a third backed Republican congressional candidates in the 2000 elections, ${ }^{23}$ the Republican Party's platform did not soften its harsh posture opposing LesBiGay civil rights protection. ${ }^{24}$ Further, the party confined the only openly gay man to address the 2000 Republican National Convention, Congressman Jim Kolbe of Arizona, to speaking on matters other than his sexuality. ${ }^{25}$ Not a single Bush campaign or administration official attended the postelection celebratory breakfast of the Republican Unity Coalition (a new political group containing LesBiGay party members). ${ }^{26}$ And, finally, it surely should come as no surprise that Bush selected John Ashcroft for Attorney General, though he views homosexuality as a sin and apparently acted on that belief as a Senator to block the appointment of gay philanthropist James $\mathrm{C}$. Hormel as American ainbassador to Luxeinbourg. ${ }^{27}$

All this is not to gainsay the recent and hard-won LesBiGay victories in a few isolated political arenas. Notably, since August 1999, two more states (Connecticut and Washington) have joined four of their sister states in extending domestic-partner health benefits to their governmental employees; and twelve more cities and counties (including Atlanta, Phoenix, and Albuquerque) now provide similar benefits, bringing the total number of such public entities in America to ninety. ${ }^{28}$ Equally important is the growing trend in state legislative and judicial recognition of LesBiGay parental rights, ${ }^{29}$ with more than twenty states formally recognizing

22. For a list of the forty-five individuals currently holding federal, state, and local offices who openly identify as LesBiGays, see The Gay \& Lesbian Victory Fund, at http://www.victoryfund.org/public/office/office.cfm (last visited Oct. 28, 2001).

23. Elizabeth Becker, Wariness and Optimism Vie as Gays View New President, N.Y. TIMEs, Jan. 26, 2001, at A1, A16 (reporting Voter News Service exit poll estimates and Republican Unity Coalition breakfast).

24. Frank Rich, The G.O.P.'s Age of Aquarius, N.Y. Times, Aug. 5, 2000, at A15.

25. Id.

26. Becker, supra note 23.

27. David Johnston \& Neil A. Lewis, Ashcroft Faces New Criticism over Stand on Ambassador, N.Y. Tmes, Jan. 26, 2001, at A16; Press Release, Hunian Rights Campaign, HRC Opposes Ashcroft Nomination for Attomey General: Long Anti-Gay History Raises Concerns that Ashcroft Won't Enforce Civil Rights Laws (Jan. 9, 2001) (on file with authors) (expressing deep skepticism over Ashcroft's ability to administer the Office of the Attorney General in a fair and impartial manner, based on HRC's review of Ashcroft's anti-LesBiGay votes during his Senate term and anti-LesBiGay commentary on the Senate floor); see also Stephen Barr, Bush Administration Remains Aloof From Goy Pride Events, Wash. Post, June 13, 2001, at B2 (after President Bush refused to follow his predecessor William Clinton's practice of issuing a Gay \& Lesbian Pride Month proclamation, the Secretary of Commerce Donald Evans ended the department's sponsorship of LesBiGay activities).

28. More Companies Offering Same-Sex-Partner Benefits, N.Y. TIMEs, Sept. 26, 2000, at C2.

29. An equally powerful trend, though interpersonal in nature, is the "nudging" that the LesBiGay partners are receiving from their parents, who no longer believe that their LesBiGay children cannot bear fruit or adopt grandchildren for them. As Cyndi Harrison, a nurse practitioner living with her partner in Los Angeles, complained: "My mother keeps telling me, 'Cone on, where's the 
second-parent adoption and a few enforcing the rights of de facto parents. ${ }^{30}$ Social acceptance for LesBiGays seems to be on the rise, at least in American urban centers. A Los Angeles Times survey in June 2000 reported that $74 \%$ of respondents claimed to be "comfortable around homosexuals" and 68\% supported equal workplace rights for homosexuals. ${ }^{31}$ Nonetheless, the Federal Bureau of Investigation's most recent annual report on hate crime statistics asserted the alarming fact that crimes based on sexual orientation increased at least $4.5 \%$ from 1998 to 1999 . The 1999 total of 1,317 reported incidents comprised $16.7 \%$ of all hate crimes committed during that year. ${ }^{32}$

Growing respect, perhaps, but still "too few rights." ${ }^{\text {"33 }}$ Put into bold relief, the political and legal picture for LesBiGays is quite clear: "Citing recent civil-rights 'advances' is rather like viewing the glass as one-fifth full, when it's really four-fifths empty . ..."34

\section{B. Commercial Gains}

In stark contrast, the commercial cup floweth over. Whether focusing on targeted product advertising, mass entertainment films and television, or corporate competition for employees, LesBiGays have become the newest

grandchild?'” John Leland, O.K., You're Gay. So? Where's My Grandchild?, N.Y. Times, Dec. 21, 2000, at F1; see also Steven Gray, New Families, New Questions; Same-Sex Couples Turn to Parenthood in Growing Numbers, WASH. Posr, Apr. 12, 2001, at T10.

30. Even so, this progress has triggered a backlash in four states: Florida, Mississippi, and Utah prohibit same-sex adoption, and Arkansas denies foster parenting to LesBiGays. John Leland, Parents' Rights: State Laws Vary, But a Broad Trend is Clear, N.Y. TIMEs, Dec. 21, 2000, at B14. (De facto parents are those who, without second-parent adoptive status, are recognized to have contributed significantly to the raising of a child.) In Florida, federal district court Judge James Lawrence King recently upheld the state's ban on LesBiGay adoptions, the first such ruling in the federal judicial system. Lofton v. Kearney, No. 99-10058-CIV-KING, 2001 U.S. Dist. LEXIS 13425 (S.D. Fla. Aug. 30, 2001); see also Tamar Lewin, Court Backs Florida Ban on Adoption by Gays, N.Y. Times, Aug. 31,2001 , at A14.

31. Brnce Bawer, More Respect, but Too Few Rights, N.Y. Times, Jan. 26, 2001, at A19 (reporting the Los Angeles Times survey).

32. See Press Release, Human Rights Campaign, HRC Calls on Congress to Pass Comprehensive Hate Crimes Legislation as FBI Releases Final Report Detailing Problem (Feb. 13, 2001). Such a sharp one-year increase in reported hate crimes based on sexual orientation is particularly disconcerting, given that overall violent crimes decreased for an eighth consecutive year and that FBI data fail to include statistics on all the notoriously underreported hate crimes based on sexual orientation. Id. For 1999, hate crimes based on sexual orientation ranked third as a category, following race and religion. The federal Hate Crimes Sentencing Enhancement Act and other federal civil rights legislation still do not include LesBiGays as a class deserving governmental protection. Hate Crimes Sentencing Enhancement Act, 28 U.S.C. $\$ 994$ (1994).

Even when local expressions of "comfort" with LesBiGays translate to support for equal treatment, these efforts may be thwarted at the national level, as the Boy and Cub Scouts of Oak Park, Illinois, discovered when they were the first seven troops to be expelled by the national headquarters for refusing to exclude gays. See William Claiborne, Scouts Expel Troops Whose Leaders Oppose Gay Ban, WASH. Post, Jan. 27, 2001, at A2.

33. Bawer, supra note 31 .

34. Amy Gluckman \& Betsy Reed, Introduction, in Homo Economics, supra note 18, at xiii. 
darlings of the commercial milieu. ${ }^{35}$ LesBiGays have been dubbed "an untapped goldmine,"36 a "Dream Market,"37 "completely underserved,"38 and "the best workers." 39 Commercial consciousness has woken up to the LesBiGay market. Now, as advertising editor Rogier Van Bakel puts it, "[C]ompamies are jumping on the bandwagon."

In the advertising arena, the bandwagon appears to be filling up rapidly. ${ }^{41}$ Absolut Vodka, the first national marketer to advertise in the LesBiGay press in $1979,{ }^{42}$ found itself in better and better company in the late 1980 s and early 1990 s, with Seagram, Hiram Walker, Miller, Calvin Klein, Benetton, Philip Morris, Columbia Records, Saab, Saturn, and Subaru commg on board. ${ }^{43}$ As for the more mainstream media, IKEA's tentative overture to LesBiGay furniture shoppers in its 1994 television commercial ${ }^{44}$ has given way to a cutting-edge crescendo of "gay-vague" advertising - that tantalizing, hip, and trendy same-sex innuendo used by many retailers to deliver an ambiguous lure to straights and a

35. For the latest incisive account of the new LesBiGay visibility in America's commercial culture and of the debate over the political and social meanings of that visibility, see generally Suzanna Denuta Walters, All the Rage: The Story of Gay Visibility in America (2001).

36. Hazel Kahan \& David Mulryan, Out of the Closet, AM. Demographics, May 1995, at 40.

37. Penaloza, supra note 19 , at 10.

38. David Kirby, The Web's User Profile Undergoes a Broad Transformation, N.Y. Times, June 7,2000 , at $\mathrm{H} 42$.

39. Press Release, Human Rights Campaign, Number of Employers Offering Domestic Partner Benefits Jumps Dramatically in One Year (Sept. 25, 2000); see also Human Rights Campaign Web Site, at http://www.hrc.org/mainset_worknet (tracking, inter alia, private employers' provision of domestic partner benefits).

40. Williain L. Hamilton, When Intentions Fall Between the Lines, N.Y. TImES, July 20, 2000, at Fl (quoting a statement of the editor of Ad Age's Creativity, an advertising industry publication).

41. Historically, the first advertiser to jump on this bandwagon was Win-Mor, whose October 1954 ad, pitching to men the sale of "festive intimate apparel-available with or without rhinestones," appeared in the publication $O N E$. Pressed with obscenity charges for its homophilic content, $O N E$ ultimately prevailed before the U.S. Supreme Court after a four-year long struggle. ALEXANDRA Chasin, Seling Out: The Gay and Lesbian Movement Goes to Market 58-59 (2000).

42. Absolut Vodka has continued to be a leader among ntarketers in aligning itself with LesBiGay causes. A recent canpaign to appear in mainstream national magazines, "Absolut Glaad," celebrates the work of the Gay and Lesbian Alliance Against Defamation ("GLAAD"). Jim Schleifer, the marketing director for Absolut at Seagram Americas in New York, noted that the ad was symbolic of "a longstanding commitment to this marketplace." Stuart Elliott, Absolute Customizes a Campaign to Salute the Gay and Lesbian Alliance Against Defamation, N.Y. Times, Feb. 22, 2001, at C6.

43. Amy Gluckman \& Betsy Reed, The Goy Marketing Moment, in A QuEER WorLD, supra note 18, at 519,520-21. In 2001, Jaguar, Volkswagen, and Volvo joined their competitors in steering their advertising dollars toward LesBiGay national publications. Subaru, which had sponsored LesBiGay award ceremonies and causes and had advertised in LesBiGay media since 1997, placed one of the sassiest ads of all the carmakers, encouraging their readers to explore the great outdoors with the clever injunction "Get out. And stay out." Cliff Rothman, A Welcome Mat for Gay Customers, N.Y. TrMEs, Aug. 17, 2001, at F1.

44. Baker, supra note 18, at 11, 17 (a television ad featuring a gay couple shopping for a dining room table played in four major markets: New York, Los Angeles, Philadelphia, and Washington, D.C.). 
direct sales pitch to LesBiGays. ${ }^{45}$ Over the six years from 1993 to 1999 , the national marketers' budget for LesBiGay-oriented advertising tripled; in one year alone, from 1998 to 1999 , it rose $29 \%$ ( $\$ 120.4$ million to $\$ 155.3$ million). ${ }^{46}$ Logic dictates that spending for gay-vague advertising vastly exceeded these numbers. ${ }^{47}$

Ironically, mainstream advertisers may be caught in a convergence of misimpressions and stereotypes that feeds their enthusiasm for the LesBiGay consumer. Whether or not overzealous reports of LesBiGay affluence sweep in the marketers, however, they must now perceive that the exact demographics of the community do not matter; after all, a substantial sector does have discretionary income, and "it does not take a lot of research to recognize that... [the LesBiGay community] is subject to trends. Once a trend catches on within a community - especially a hip urban one-there is a good chance it will spread elsewhere." ${ }^{\prime 48}$ And whether or not advertisers naïvely believe that all LesBiGays are starving for attention and vulnerable to commercial exploitation, ${ }^{49}$ they must now appreciate

that some LesBiGays will indeed pay for pride. It is to be expected that LesBiGay "[a]ssimilationists may try to buy acceptance by buying into consumer society," or that "A-Gays may invest in fantasy lifestyles decorated with symbols of superiority." consumers may even reward pandering advertisers with brand loyalty. As one Hiram Walker manager once put it, "I have a file of letters an inch or two thick from gay consumers thanking us and vowing their loyalty.... A straight consumer wouldn't take the time and say thank you for validating us." 51

At bottom, the rapid rise in LesBiGay advertising may be explained by nothing more than the realization that probable gains outweigh potential risks. Any economic losses sustained from feeble protests by the Far Right have been offset by profits from LesBiGay purchases. John Slowick, Jr., ex-publisher of Out magazine, remarked pointedly, "Our demographics are

45. William L. Hamilton, When Intentions Fall Between the Lines, N.Y. TimEs, July 20, 2000, at F1, F4 (reporting that Michael Wilke, a former reporter at Ad Age magazine, coined the term "gayvague" for advertisements targeting both LesBiGay and mainstream audiences); CHASIN, supra note 41 , at $140-41$.

46. Spending Increases in Gay Magazines, N.Y. Times, June 12, 2000, at Cl6.

47. Unfortunately, hard statistics are not similarly available for this recent trend of purposefully ambiguous commercial advertising.

48. Baker, supra note 18 , at $11,13$.

49. Kahan \& Mulryan, supra note 36, at 40 ("[G]ay men and lesbian women show their gratitude to marketers who have the courage to serve them. In return for what they see as acceptance or respect, gay consumers will go out of their way to patronize these companies.").

50. Per Larson, Gay Money, VICTORY!, Jan./Feb. 1996, at 12-13 (defining "A-Gays" as LesBiGays who maintain social status in large part through high-style consumerism).

51. Nancy Coltun Webster, Playing to Gay Segments Opens Doors to Marketers, AdVERTISING AGE, May 30, 1994, at 6. 
more appealing than those of eighty-year-old Christian ladies." 52 Levi Strauss understood as much im 1993 when a boycott of its products, organized by Reverend Donald Wildmon of the American Family Association in retaliation for the company's pro-gay stance, failed to affect the jeans maker's year of record-breaking profits. ${ }^{53}$ Ultimately, marketers know that, in this realm, they are winning the game by familiar rules. ${ }^{54}$ In capitalist America, the wheels of fortune turn with money: "There's a market here; there's a buck to be made." $" 55$

\section{Celluloid Reflections}

If Madison Avenue has been fiirting heavily with LesBiGays as of late, surely Hollywood has climbed enthusiastically imto their beds. Contemporary films depict more LesBiGays than ever before, and the characters are increasingly positive, charming, and life-affirming. ${ }^{56}$ The guilt-laden pathos of the "invert," portrayed in sporadic, earlier films like The Children's Hour ${ }^{57}$ and Boys in the Band, ${ }^{58}$ has surrendered either to the high camp of comedic figures such as the transvestite Zaza in La Cage aux

52. Gluckman \& Reed, supra note 43 , at 519.

53. Bradley Johnson, Far Right Attacks Losing Out to $\$ \$$, ADVERTISING AGE, May 30, 1994, at 7.

54. Interestingly, one of these rules, at least in the context of the advertising executive workplace, may still be "don't ask, don't tell." Reports Jack Sansolo, one of the first major executives of a mainstream advertising agency to come out of the closet with few to follow in his footsteps: "Clearly, there are a lot of gay people in sernor positions [at advertising agencies]. But you still don't see a lot of them coming out." Stuart Elliott, Advertising: An Informal Survey Finds Don't Ask, Don't Tell Is Still Observed on Madison Avenue, N.Y. TMES, June 26, 2000, at C16. But, Thomas Cott, president of New York's "Out Professionals," delivers a more hopeful perspective: "The younger generation is a lot more comfortable with being out... [T] here's now more support for people who come out." Id.

55. Johnson, supra note 53, at 7 (quoting Ms. Torie Osborn, former National Gay and Lesbian Task Force executive director). For a collection of print advertisements and television commercials featuring LesBiGays around the world, see The Commercial Closet, at http://www.commercialcloset.org (last visited Oct. 28, 2001).

56. See Vito Russo, The Celluloid Closet: Homosexuality In the Movies (rev. ed. 1987). Russo's book, arguably the definitive historical account of homosexuality in cinema, has been rendered in an impressive film that features a host of celebrity narrators. The Cellulord Closet (Columbia/TriStar Studios 1997). Similar to the dynamics operating in Madison Avenue executive offices, see supra note 54, "[t] $]$ here is widespread agreement in Hollywood that if an actor aspires to the kind of visibility and clout currently enjoyed by [Tom] Cruise or Tom Hanks or Julia Roberts in movies, or Oprah Winfrey on television, he or she had better stay in the closet-at least for now." Richard Natale, A Glimpse Outside the Closet, L.A. TIMEs, July 15, 2001, at 4.

57. The ChILDREN's Hour (Metro-Goldwyn-Mayer 1961). Based on Lillian Hellman's 1934 play, the filn features Shirley MacLaine in the unflattering role of a girls' school marm who tearfully confesses love for her cosupervisor, played by Audrey Hepburn. At that point, of course, there is no other solution for MacLaine than to hang herself.

58. The Boys IN THE Band (Twentieth Century Fox 1970). Putting aside the historical importance of one of the earliest major studio productions to focus entirely on gay characters, few movies have pictured an entire group of same-sex friends in as bleak or unforgiving a way. From one moment of sturm und drang to another, the film reveals each character's multiple layers of personal dysfunctionality, until the viewer is left to wonder which one is the inost bitter, angry, isolated, lonely, despairing, or irreparably damaged. 
Folles $^{59}$ and the drag queen, Arnold, in Torch Song Trilogy, ${ }^{60}$ or to the higher taste of stylish and sensitive LesBiGay friends so often found at weddings, as in Four Weddings and a Funeral $l^{61}$ and My Best Friend's Wedding. ${ }^{62}$ Importantly, production companies now realize that there are sizeable audiences for art films and bigger-budget pictures that celebrate the productive lives and self-accepting loves of LesBiGays, whether the run-of-the-mill types in Trick ${ }^{63}$ and The Incredibly True Adventures of Two Girls in Love, ${ }^{64}$ or the extraordinary icons in Personal Best ${ }^{65}$ and Wilde. ${ }^{66}$ The fantasy machine of modern filmmaking is fueled by images of LesBiGays: more ecstatic, more unconditional, and sexier images than could have been thought possible twenty-five years ago.

Not to be left out in the cold, commercial cable and network television corporations have entered our living rooms with their own mainline versions of the humpy, happy queer. Showtime's rave-reviewed 1993 experiment with Tales of the City, ${ }^{67}$ the hilarious and poignant chronicle of San

59. LA CAGE AUX Folles (United Artists 1979). Based on the hit play of the same name by Jean Poiret, this zany, warm-hearted French farce about an aging transvestite and his partner, who are guilttripped into portraying a straight married couple in a social situation that goes from bad to worse, sent the encouraging message that LesBiGays should flee the closet and "be themselves." The National Board of Review named it Best Foreign Film of 1979, and it also won the Foreign Press Association's Golden Globe for Best Picture of the Year. See Awards for La Cage Aux Folles, at http://us.imdb.com/Tawards?0077288 (last visited Nov. 2, 2001).

60. Torch SONG TrilogY (New Line Cinema 1989). In this film, Harvey Fierstein recreated his Broadway role as a New York drag queen who seeks love, respect, and tradition from his families of origin and of choice, all in a world not well designed for his preference package.

61. Four WedDings ANd a Funeral (PolyGram Film Productions 1993). A dynamic gay male couple furnishes the primary example of a loving and committed relationship in this film, contrasting with the occasional sexual encounters in which actors Hugh Grant and Andie MacDowell engage as they unexpectedly meet and remeet as invited guests at a series of weddings.

62. MY Best Friend's WedDing (TriStar Pictures 1997). Actor Rupert Everett co-stars as the suave, debonair, and eloquent gay friend who provides an emotional lifeline to Julia Roberts as she attempts to steal back her childhood friend, with whom she now realizes that she is in love, on the very weekend of his wedding to another woman.

63. TRICK (Fine Line Features 1999). Two hunky and hopeful gay romantics try to make it (litcrally) in a one-night stand in the Big Apple, but are interrupted by a stream of chaotic and hilarious events. From the first strain of the opening music, "Enter You-Voilá, It's Showtime," the sexual teasing is non-stop.

64. The Incredibly True Adventures of Two Girls in Love (New Line Studios 1995). Expressing the deepest meanings of first love, racial clashing, and class conflicts, this film succeeds as a compassionate and untormented lesbian story.

65. Personal Best (Warner Studios 1982). A classic of the lesbian mainstream cinema, this movie features actress Mariel Hemingway as a young runner who reaches a final, triumphant qualifying race for the boycotted 1980 Moscow Olympic Games via an affair with her mentor-competitor, Olympic runner Patrice Donnelly.

66. WILDE (Columbia/TriStar Studios 1998). A big-budget profile of Oscar Wilde, the film focuses compellingly and sympathetically on the events surrounding Wilde's 1895 sodomy trial and conviction.

67. TAles of THE City (Channel Four Television Corporation 1993). Broadcast on Showtime's "American Playhouse," Armistead Maupin's best-selling novel came to life in the marvelous depiction of the antics at 28 Barbary Lane. Olympia Dukakis stars as Anna Madrigal, the zany landlady who 
Francisco's gay-friendly life in the 1970s, appeared to stiffen the spines of network television producers. Within a very short time, they have moved from tentative to bold in their delivery of LesBiGay programming. Ellen DeGeneres's timid declaration of her lesbianism on $\mathrm{ABC}$, heard sotto voce during the "coming out" episode of Ellen on April 30, 1997, ${ }^{68}$ was soon overwhelmed by the screaming "queeniness" of actor Sean Hayes, who plays the flamboyantly funny Jack McFarland of Will \& Grace (a role for which he received an Emmy Award in 2000). ${ }^{69}$ Yet, nothing quite outdoes the inost recent cable television foray into LesBiGay mass entertainment: Queer as Folk, Showtime's titillating series of "sexploits" involving a tight-knit circle of gay and lesbian friends. Hyped by a promotional blitz exceeding $\$ 10$ million, the largest ever for a Showtime series, ${ }^{70}$ Queer as Folk consciously and unapologetically assumes the LesBiGay perspective. ${ }^{71}$ In a real sense, then, today's commercial television culture is eager to be radical-to "walk on the wild side."72 The Village Voice critic

welcomes her tenants by taping homegrown marijuana joints to their doorframes and who presides over their lives, sexual and nonsexual.

68. Ellen DeGeneres's hesitant and insecure avowal in the now-famous "Puppy Episode" of Ellen played to "coming out" parties held across the nation, and garnered an audience of over thirty-six million viewers. See Ellen Uncensored (May 6, 1998), at http://members.tripod.com/ $\sim$ moon_goddess_666/moon_goddess9_ellen.html (last visited Nov. 2, 200I) (transcript of Diane Sawyer interview with Ellen DeGeneres on ABC Primetime).

69. West Wing, Will \& Grace Named Top Shows at Emmys, Mr. SHowbiz (Sept. 10, 2000), at http://www.mrshowbiz.go.com/newsarchive/news/2000/9/eminys091000.html. Will \& Grace swept the comedy category at the 52nd Annual Emmy Awards celebration, held on September 10, 2000, receiving three Emmys. The show won for Best Comedy Series, and the comic relief duo of Sean Hayes (Jack) and Megan Mullally (Karen) took hoine an Emmy apiece. One year earlier, Will \& Grace had won the People's Choice Award for Favorite New Comedy.

70. Stuart Elliot, The Showtime Network Prepares a \$10 Million Campaign Blitz for Its Queer as Folk Series, N.Y. Tmes, Nov. 28, 2000, at C10. For one example of such advertising in magazines, see also ENTERTAINMENT WEEKLY, Oct. 6, 2000, at 19 (billing the Showtime original series as having "no limits").

71. Caryn James, In a Gay World, Without the Usual Guides, N.Y. Trmes, Dec. 3, 2000, at 27. The "gay perspective" projected by "Queer as Folk" is not viewed as totalizing by certain LesBiGay folk, as gay television critic Anthony Tommasini made clear in his rather condemning review of the Showtime series. He caustically sums up its main theme: "[B]eing gay is all about sex. And on this trip you will see it all: gay images, exploits, pinings and positions." Topping his complaints, Tomnasini states: 'Nothing in 'Queer as Folk' bothers me more than the absence of straight people, of either sex, from this gay circle. lt seems so unnatural, so at odds with the issues of inclusiveness and commonality that concem the gay community right now. And just when things were getting better." Anthony Tommasini, Looking for a Breakthrough? You'll Have to Wait, N.Y. Tmes, Jan. 14, 2001, at 2-33, 238.

After shedding so much attention on the gay male world in "Queer as Folk," Showtime made a half-hearted effort to balance cable TV's same-sex perspective for lesbians, running a two-part, fourhour anthology called "A Girl Thing" in mid-January, 2001. The anthology involved four psychotherapeutic sessions, held with actress Stockard Channing, that revcaled the escapades of lesbian and bisexual women in a series of compromising situations. See Julie Salamon, Gay Women Get a Turn, Although Not Equal Time, N.Y. Tmes, Jan. 19, 2001, at B33 (reviewing "A Girl Thing”).

72. Long associated with sexual slumming, this phrase canne into mass media currency with the 1962 Columbia Pictures film, Walk on the Wild Side, and was remvented by Lou Reed's key track on his album Transformer, released in 1972. 
Richard Goldstein sums it up well: "Homophobia may still be a currency in Congressional politics; gay rights bills may be stalled in many states ...; but in the land of $\mathrm{Oz}$, where the American imagination plays, something has definitely changed."73

\section{Employment Benefits}

Like Dorothy in The Wizard of $\mathrm{Oz}$, LesBiGays on cineına and television screens may not be in Kansas anymore. But when the picture turns to the corporate workforce, LesBiGays are in Kansas, and in all of the

73. Richard Goldstein, Queering the Culture, THE VILLAGE VoICE, June 30, 1998, at 38, 44; see also A Special Report on Gay Hollywood 2000, ENTERTAinment WeekLy, Oct. 6, 2000, at 23-49 (including stories entitled Is Your TV Set Gay? From Ellen to Will \& Grace, How Television Led a Cultural Revolution; Calling Their Own Shots: Four Gay Filmmakers Dish the Dirt on the State of the Movie Industry; Coming Out Soon: It's (Almost) Here, It's Queer-A Guide to What's Next in Movies, TV, Music, and Theater; The Gayest Show on Earth: A Sneak Preview of . . 'Queer as Folk'; and Yep. They're Gay: IOI Movers \& Shakers).

It goes without saying that, for LesBiGays, the commercial mass entertaimment land of $\mathrm{Oz}$ is not reserved to the cinema and television industries. LesBiGay music marketing is increasingly prominent, as the compilation CDs packaged for gay classical music lovers, such as Sensual Classics, Too (Teldec) and Out Classics (RCA), and those targeted to lesbians, such as Classical Erotica (Rising Star), richly demonstrate. Homoerotic jewel case art enabled these recordings to hit Billboard's Top Classical Albums chart in 1996. See James Hannahan, Feeding the Gay Market, Out Magazine, Nov. 1996, at 117-18. And in pop music, the first post-LesBiGay liberation star, Rufus Wainwright, a twenty-sevenyear-old singer-songwriter, is the idol of "teenage girls who love him, although they know he would rather date their older brothers." Ann Powers, Embracing Gay Identity with Candor and Pride, N.Y. TIMEs, July 1, 2001, at 2-24.

Furthermore, LesBiGay presence in Broadway and Off-Broadway theatrical productions, historically a matter of same-sex actors playing straight roles, now cxtends equally to same-sex subject matters. As Richard Goldstein quipped about New York's plethora of LesBiGay theater offerings in the summer of 1998:

In the same week Trent Lott dusted off his jackboots and compared homosexuals to kleptomaniacs, a New Yorker with an open mind could fill every evening with gay entertainment. Even as fanatics tried to suppress a gay Jesus play, one could watch Oscar Wilde kiss his beloved Bosie in venues on and off Broadway. Or marvel at Peggy Shav plumbing the depths of menopause in a business suit. Or glam it up with a hard-rocking transsexual named Hedwig. Or slather over Shakespeare's $R \& J$, an all-boy version of the quintessential hetero text.

Goldstein, supra note 73, at 39 . In the sports arena, commercial marketing has taken on new faces for new audiences. Advertisements feature open LesBiGay athletes who encourage LesBiGay fans to attend sports events or to buy commercial products. See, e.g., Stuart Elliott, A Natural Marketing Alliance Finally Takes Some Tentative Steps: Gays in Sports, N.Y. TIMES, July 9, 2001, at C9; Tom Weir, WNBA Sells Diversity: Marketing Recognizes Lesbian Fans, USA TODAY, July 24, 2001, at 1C (nine of sixteen WNBA teams pitch some direct marketing to lesbian fans).

Moreover, the realms of cyberspace are certainly not foreign territory for LesBiGays. Beyond the same-sex "pornutopia" that the Internet spawns, LesBiGays are preferred customers on large portals such as Gay.com and PlanetOut that offer everything from shopping, book clubs, personal ads, and chat rooms to support for living with HIV, investment planning, and hyperlinks for LesBiGay businesses. See Kirby, supra note 38; Martin Arnold, Transition Time for Gay Works, N.Y. TIMES, May 10, 2001, at $\mathrm{E} 3$ (the LesBiGay book club, www.insightoutbooks.com, is "one of the most important new forces in gay publishing" now that many LesBiGay bookstorcs have gone out of business as mainstream stores sell such literature). 
forty-nine sister states, as well. ${ }^{74}$ Across America, many company managers have realized that LesBiGay employees are extremely valuable, and must be treated equitably in order to be recruited and retained. ${ }^{75}$ Extension of domestic partnership benefits thus has become an increasingly standard private business practice. Jere Drummond, cochair of the Diversity Council at BellSouth Corporation in Atlanta, characterized the growing attitude among employers: "We know that to remain competitive, we must attract and retain a work force that reflects the diversity of the communities we serve." 76 For BellSouth, the last of the Baby Bells to announce its policy of equal treatment, the commitment to a first-rate beneflts package for LesBiGay domestic partners includes medical, dental, life and accidental death and dismemberment insurance, and family and medical leave.

Similar entitlements have been granted by whole market sectors, including several of the "old economy" industries. Within the month of June 2000 alone, the Big Three auto manufacturers (Ford, General Motors, and Daimler-Chrysler) trailed Subaru of America in adopting domestic partnership benefits; among food producers, Coca-Cola joined General Mills and Pillsbury. ${ }^{77}$ Four months later, Boemg followed Honeywell's lead as the second aerospace contractor to provide benefits to its nonunion employees. ${ }^{73}$ Withm the same year, eight of the ten largest passenger airlines signed on (TWA and Alaska Airlines being the two exceptions). ${ }^{79}$

74. Indeed, LesBiGays reside in nearly every American county, as data from the 2000 Census demonstrate. See Households Headed by Gays Rose in the 90's, Data Shows, N.Y. TIMEs, Aug. 22, 200I, at A17 (same-sex couples head nearly 600,000 homes throughout the United States); see also Press Release, Human Rights Campaign, U.S. Census Figures Continue to Show National Trend of Dramatic Increase in Households of Same-Sex Partners (June 27, 2001).

75. Such recognition has translated to official antiharassment policies for some private corporations, although "the face of antigay bias in the workplace has evolved from that of overt discrimination to one of more subtle prejudices." Joseph Hanania, Bias Against Gays Today Often Subtle, Sometimes Not So; Some Defuse Tensions by Confronting, Ignoring or Sidestepping Their Harassers, L.A. Times, Feb. I8, 200I, at WI (quoting a statement of Jon Davidson, director of Los Angeles Lambda Legal Defense \& Education Fund).

76. Press Release, Human Rights Campaign, BellSouth Becomes Last of Former 'Baby Bells' to Announce Domestic Partner Benefits (Dec. I5, 2000) [hereinafter Press Release, BellSouth].

77. Press Release, Human Rights Campaign, Number of Employers Offering Domestic Partner Benefits Jumps Dramatically in One Year (Sept. 25, 2000) [hereinafter Press Release, Number of Employees]; Press Release, BellSouth, supra note 76. For the latest updates on the Huinan Rights Campaign statistics, see its website at http://www.hrc.org/mainset_worknet.

78. See The Boeing Co., Compensation and Benefits, at http://www.boeing.com/ companyoffices/empinfo/compensation/ (last visited Sept. 15, 200I). Interestingly, the preamble to Boeing's Health \& Welfare Plan for Same-Gender Domestic Partner Coverage highlights the profit goals motivating its largess: "[T] be the "employer of choice' we need to be prepared to provide benefit plans and prograins that will help us recruit and retain valuable employees." The Boeing Co., Health and Welfare Benefits, Same-Gender Domestic Partner Coverage, at http://www.boeing.com/ companyoffices/empinfo/compensation/totalcomp/health/domestic_partners/FAQ New.htm (last visited Nov. 30, 2001).

79. Press Release, Number of Employees, supra note 77; Press Release, BellSouth, supra note 76. 
The total number of private employers now offering domestic partnership benefits approximates 3,500 , a figure thirty-five times the number of state or local governments and agencies providing LesBiGay benefits packages. ${ }^{80}$ Importantly, the total number increased $25 \%$ in one year alone, from August 1999 to August 2000, and the list currently includes approximately one-fifth of the Fortune 500 companies and $82 \%$ of the Fortune 50 . The domino effect in these major industry sectors is likely to continue, more for solid and pragmatic business reasons than for reasons of antidiscriminatory ideology.

Advertising, entertainment, and employment-three of the most prominent routes paved by the American commercial culture. Over all three routes, LesBiGay identity has become all the rage. Why might LesBiGays favor such a commodified identity? What do these commercial routes promise to LesBiGays? Have anger, frustration, and passive victimhood-all justifiable reactions to a vacuum of real sociopolitical power-merely been seduced and silenced by the fantasy images of personal consumption? Or are there positive and powerful forces to be unleashed as LesBiGays embrace their commodified identities? This Essay answers these questions in the next section by exploring the underlying commercial framework.

II

\section{The Commercial Coding of LesBigays}

\section{A. Sexuality and Commerce}

Sexuality is commerce, commerce is sexuality. ${ }^{81}$ They are linked in the modern American mindset, as a bevy of popular and legal metaphors reveal. In matters of romance, singles are "in the market." A newlywed couple enters into a "marriage contract." And, as young parents, they "produce offspring." In matters of business, we engage in "commercial

80. Press Release, Number of Employees, supra note 77.

81. All too often, the terms "sexuality" and "sex" (as organs or acts) are used synonymously in ordinary discourse. As "sexuality" is not merely a function of having certain "sex" organs, or of performing certain "sex" acts, it is important to recognize the fundamental differences between the terms. Nevertheless, when discussing the theoretical connections between commerce and sexuality, it is virtually impossible to separate out the commodified strands of sex and sexuality, if for no other reason than that the very language of advertising purposefully collapses them. See generally ERviNG GOFFMAN, GENDER ADVERTISEMENTs (1979) (discussing gender \& the allure of advertising); SUT Jhally, The Codes of Advertising 132-39 (1987) (same); Judirh Williamson, Decoding ADVERTISEMENTS 120-21 (1978) (unpacking the semiotic meaning of particular ads in terms of both sex and sexuality). For fascinating accounts of the theoretical interplay of capitalism, commercialism, and sexuality that go well beyond the scope of this Essay, see generally MrCHEL FoucaulT, THE History of Sexuality: AN INTroduction (1990); Jean Baudrillard, Symbolic Exchange and DEATH (1976) (particularly, the discussion of the sexual carnival in "The Body or the Carnality of Signs"); Marshall McLuhan, The Mechanical Bride (1951). In this Essay, the terms "sexuality" and "sex" refer simultaneously to both, unless the text explicitly provides otherwise. 
intercourse." Usurping shareholders can "sterilize" a corporate board. Those same shareholders might be liable if a court "pierces the corporate veil." And the reasonable person knows that, whether playing in the realms of sex or of commerce, "prophylactic measures" are de rigueur.

The ineluctable link between sexuality and commerce is far more than metaphorical, however. In our advanced capitalistic culture, the regimes of profit rely upon the regimes of sexualized pleasure, and vice-versa. Commodities sell sexuality, and sexuality sells commodities. Day after day, America's captains of commerce tender ever more daring depictions of erotic life to hawk their wares. ${ }^{82}$ Images of women and men that capture their bodies, their sexual mystique, and their sexualized encounters are commercially exploited to sell everything from cars to cologne. In a real sense, commerce pimps its products.

The modern mass advertising process models perfectly the symbiosis between sexuality and commerce. Advertising seizes upon sexuality and imagistically associates it with products and services. By this process, a subtle but significant metamorphosis occurs. The symbols, meanings, and values of sexuality are infused into products and services, just as the symbols, meanings, and values of products and services are simultaneously infused into sexuality. After reworking the cultural meanings of both sexuality and commodities, advertising transimits those meamings back into America's marketplace of items and ideas. Thus, commercial advertising not only refiects images of sexualized commodities and commodified sexualities, but it also constitutes them. ${ }^{83}$

Today's American citizen-consumers, with their overwhelming bias toward expressing private identities and lifestyles through material purchases, are inured to viewing their sexualities as commodities. "[O]ur very images of our own body, our own selves, our own personal self-worth (or lack of it) is mediated by the omnipresent [commercialized] images of mass culture." 84 We have come to terms with our sexuality not only "as bio-political acts, drives, dysfunctions, 'the Big O,' health, pleasure, and happiness, but also with sexuality as commodities." ${ }^{85}$ Hyper-masculine sexuality-with its stereotypes of dominant power, aggressive achievement, hard-hitting play, and mind-blowing orgasms-is defined by the avid use of male-identified products, whether tailored business suits, sleek

82. A compact but informative historical account of sex as an advertising device that describes its increasing frequency and audacious imagery is given in CharLes Goodrum \& HeLEN DALRYMPLE, AdVERTISING In America: The First 200 Years 68-81 (1990).

83. Ronald K. Colins \& David M. SKover, The Death of Discourse 71-81, 151-52 (1996) (exploring in greater depth the workings of commercial advertising as a phenomenon).

84. Douglas Kellner, Critical Theory, Commodities and the Consumer Society, in THEORY, Culture, and Society: EXplorations in CRitical Social Science 66 (1983).

85. David T. Evans, Sexual Citizenship: The Material Construction of Sexualtries 45 (1993). 
sports utility vehicles, or fantasy-fulfilling pornography. As the thriving industries of fashion, cosmetics, interior design, and home appliances demonstrate, product consumption also reinforces traditional feminine sexuality, with its stereotypes of eye-catching beauty, flirtatious submission, and artful homemaking. ${ }^{86}$

LesBiGay identities, too, are constituted as commodities. Though it may seem ironic that a counter-cultural sexual identity might exist primarily as a function of core-cultural commerce, American LesBiGay identity cannot be understood apart from commerce. Whether it be personal acknowledgeinent as a same-sex individual or collective recognition as a same-sex community, LesBiGay identity owes much of its historical origins and modern evolution to the capitalist economy and commercialized marketplace.

\section{B. The Capitalistic Origins of LesBiGay Identity}

Historically, capitalism created the socioeconomic conditions that fostered possibilities for a same-sex personal and collective identity. By divesting the agrarian household of economic self-sufficiency, moving single laborers to urban industrial centers, and separating sexual pleasure from procreation, capitalism enabled American men and women to focus their erotic and emotional attentions upon members of their own sex. As gay historian John D'Emilio explains:

Only when individuals began to make their living through wage labor, instead of as parts of an interdependent family unit, was it possible for homosexual desire to coalesce into a personal identity-an identity based on the ability to remain outside the heterosexual family and to construct a personal life based on attraction to one's sex. ${ }^{87}$

By the end of the nineteenth century in America, discrete urbanized groups of men and woinen, self-identified as homosexual, viewed their same-sex orientation as a trait that distinguished them from the heterosexual majority, and sought each other out for sexual and emotional relationships.

86. The commodification of women focuses centrally on their household role as "shoppers-inchief," as critical theorist Rosalind Coward explains: "To be a woman is to be constantly addressed [and] scrutinized, to have our desire constantly courted-in the kitchen, on the streets, in the world of fashion, in films and television.... Desire is endlessly defined and stimulated. Everywhere female desire is sought, bought, packaged and consumed." Rosalind CowARD, Female Desires 13 (1984).

87. John D'Emilio, Capitalism and Gay Identity, in POWERS OF Desire: The Politics of SEXuality 100, 104-05 (Ann Snitow et al. eds., 1983). In his focus on the forces of nineteenth century capitalism, John D'Emilio's account of the origins of same-sex identity bears compelling parallels to Michel Foucault's account of the creation of sexuality, both "normal" and "perverse," by the eighteenth and nineteenth century public discourses of medicine, psychiatry, criminal justice, and parental or social control of adolescent behaviors. See generally FouCAuLT, supra note 81 (discussing the multiplication and intensification of Western discourses on sexuality, and the operations of power in discursive production). 
Moreover, the early twentieth century witnessed the genesis of LesBiGay communities in large cities such as New York and Chicago, where samesex bars and bathhouses, private clubs, literary circles, and settlement houses provided the first gathering spots for LesBiGay social circles. ${ }^{88}$

Capitalist economics and commercialization have also played key roles in developing the modern American LesBiGay identity. The market's impact on gay male identity may be the most evident, if for no other reason than that upper- and middle-class gay men enjoy some of the patriarchy's economic clout. As gays increasingly staked out their own expensive leisure and lifestyle markets over the past thirty years, the commercial marketplace staked them out in turn, colonized and exploited their sexuality, and offered alluring visions of the active, freewheeling, and unfettered commercial pursuit of the "good gay life." The gay male identity has transformed radically from the "sissies," "fags," and "losers" of the '50s and ' $60 \mathrm{~s},{ }^{89}$ as it has been commodified into the newer styles of buffed-out and erotically charged manliness: working out his muscles in the gay gym, ${ }^{90}$ working out his energy in the gay disco, working out his stress on the gay cruise, and working out his libido in the gay bathhouse. "The potency of the modern honiosexual nuale's "virilization," sociologist David Evans posits, "is as much economic as it is sexual, [as he is] allowed to exercise his rights as consumer."91 Perhaps nothing better captures today's commodified gay male sexuality than the continuing commercial success of the gay bathhouse, backroom, or "jack-off club," all of which still "facilitate[] the pursuit of homosexual encounters with consummate efficiency."

Commercial capitalism's inipact on the modern lesbian identity is no less substantial, though perhaps less obvious. Though wonien surely wrapped themselves in each other's arms even when under the unsuspecting eyes of their boyfriends or husbands, it was not until women began to unburden themselves of economic dependency on men that they were free to live as lesbians. ${ }^{93}$ Once freed $\mathrm{m}$ this fashion, many lesbians burned their

88. D'Emilio, supra note 87, at 105-07. See also generally George ChauncEY, Gay New YoRK: GeNder, URBAN CUlture, AND the MAKING OF THE GAY MALE WorLd, 1890-1940 (1994); Lillian Faderman, Odd Girls and Twilight Lovers: A History of Lesbian life in Twentieth-Century AMERica (1991).

89. David T. Evans, Sexual Citizenship: The Material Construction of Sexualities 94-103 (1993).

90. For an amusing account of a recent gay émigré who became "a total slave to the gym rhythm" in Los Angeles, see Peter Whittle, Perspective: Time for This Gym Rat to Break Free from the Pack, L.A. Times, Apr. 5, 2001, at El.

91. Evans, supra note 89 , at 100.

92. Id. at 103.

93. Social commentators Amy Gluckman and Betsy Reed instruct us in this regard:

As women have won more access to economic resources, it has become easier for them to eschew heterosexual marriage, building their own households, communities, and institutions. Indeed, as droves of women have entered the workforce, marriage rates have declined; the share of women who are married dropped from 71 percent in 1970 to 60 percent in 1993. 
bras and chucked their makeup, traded their high heels and camisoles for steel-toed work boots and denim shirts, gave up their toasters in exchange for tools, and took to the hills to commune. These lesbian pioneers bought out of commercialism's creed for the conventional woman, but not for long. Today's lesbians have bought right back into fashion faiths, on whichever side of the GAP they choose to tithe. "This [is the] era of "lipstick lesbians," claims Frances Stevens, publisher and editor-in-chief of Deneuve, a lesbian style magazine. "These women are finally deciding that just because they're lesbian, it doesn't mean they have to cut their hair off and buy flannel shirts." And mainstream marketers are paying attention, ready to commodify the trendy lesbian's sexual identity, whether lipstick, butch, or androgynous. Indeed, ad execs bank on the belief that the modern lesbian will pay for a commercially cultivated identity all her own. ${ }^{94}$ "These people don't read Better Homes \& Gardens," Stevens posits. "They see an ad for a tampon in Deneuve, they'll change their tampon brand."

Whether associated with tampons or tee-shirts, cruises or cruising, LesBiGay identities have been commodified, and they are among America's hottest. Heat is a matter of degree, however, and several key questions linger. When LesBiGays are put into the commercial spotlight, are they likely to find nurturing warmth there? Or will the intensity of the glare dazzle and deceive them as to the mythical character of the marketplace? Or blind them to the plight of less privileged LesBiGays? When LesBiGay identities are fired in commerce's furnaces, will they form to molds of their own making? Or will they be mere clay for commercial shaping? Only time will tell, of course, but capitalism may well kindle complex and contradictory effects.

Compared to being ignored, shunned, and assaulted, it feels pretty good to lounge on an R.S.V.P. or Olivia cruise ship, sipping an Absolut martini, draped with a Rainbow Flag towel, while listening to kd lang's "Invincible Summer" disc. In this sense, capitalism works on more than a monetary level. For many LesBiGays, commercial attention works on a deeply emotional level as well. Having a commodified identity means more than buying and selling; it can also mean feeling "wanted" and socially "validated." As marketing professor Lisa Penaloza observes, "[I]n a capitalist society, market incorporation is of the utmost importance because it summons a social legitimation approaching that of citizen." 96 Generally speaking, LesBiGays are famished for the recognition and acceptance of citizen-consumers, and this is a hunger that commerce has

Gluckman \& Reed, supra note 34, at xxii.

94. Bradley Johnson, Economics Holds Back Lesbian Ad Market: "Want Something Totally Their Own," Publishers Say, Advertising Age, Jan. 18, 1993, at 34.

95. Id.

96. Penaloza, supra note 19 , at 33 . 
noticed and is eager to sate. ${ }^{97}$ For instance, when the T.V. program Northern Exposure broadcast its first lesbian episode, the network was overwhelmed with letters of praise from lesbian viewers. The episode's writer recalled, "[T]hey were very grateful, like starving people getting a crust of bread." ${ }^{\text {" }}$ bite the only hand that feeds them.

The commercial marketplace also offers an agora for LesBiGays. From the perspective of the closet, it is progress for the LesBiGay identity to be pitched in advertising, pictured in film, portrayed in television programs, and projected in corporate hiring goals. Where once the public sphere silenced LesBiGays, it now broadcasts LesBiGay speech, albeit commercial speech. Moreover, the commodified identity is itself a form of "voice." As LesBiGay identity is talked to, and as it talks back, LesBiGays essentially speak their way into being, at the very least a commercial being. Whereas LesBiGays once shared "the Love that dare not speak its name,"99 they now share a commercialized love that never shuts up.

Engaging in dialogue within the marketplace, LesBiGays have found a real opportunity to exert some new control over their identity formation. Capitalism constructed the earliest identities of American LesBiGays, and typically outside of their influence. LesBiGay identities are now, and will likely always be, commercially constructed. The important difference, however, is that LesBiGays today increasingly participate in the construction of their commodified identities, whether as discerning producers or as discrimmating consumers. ${ }^{100}$ In other words, in turn for being commodified, LesBiGays may become commercial agents in their own right. In this sense, LesBiGays have discovered that the modern commercial marketplace functions as an important site of social contestation. And this is a contest that they appear to be winning. ${ }^{101}$ LesBiGay cultural images are less pathetic, more admirable; less hateful, more lovable; less unalike, more equal; less perverse, more "normal."

97. For a succinct synthesis of leading theoretical perspectives on the relationship of American citizenship to marketplace access, see Anthony J. Freitas, Belongings: Citizenship, Sexuality, and the Market, in Everyday Inequalities: Critical InQuiries 361, 363-68 (Jodi O'Brien \& Judith A. Howard eds., 1998).

98. Gluckman \& Reed, supra note 43, at 519, 524 (quoting Andrew Schneider, the writer of Northern Exposure's lesbian episode).

99. Lord Alfred Douglas, Two Loves, in I The Chameleon 28 (1894).

100. See Sue Levin, In The Pink: The Making of Sucessful GaY-And Lesbian-Owned BUSINESSES (1999). For the entrepreneurial LesBiGay, this pathbreaking book is one of the most instructive manifestoes for building profitable businesses.

101. . . . at least the Caucasian upper-class LesBiGays. It is critical always to remember that the commercial playing field is uneven given racial, ethnic, gender, and class differences. Nevertheless, it is equally important to recognize that the trajectory of commercialization's effects may be similar for most LesBiGays over time, even though relative scales and speeds of change will vary. It is the dynamic of the trajectory that this Essay explores. 


\section{Mythmaking in the Marketplace}

Admirable, lovable, equal, normal .... Does it matter if any of these commercial images for LesBiGays is true? Does it matter if the marketplace has merely created LesBiGay myths for the larger masses? Any meaningful answer to these questions depends entirely on a profound understanding of commercial mythmaking. Indeed, American society's mythmaking may turn the very wheels of its commerce.

Commercial myths are generally spun for both aspirational and regulatory reasons. ${ }^{102}$ Aspirationally, all marketplace myths enrich the values that promote capitalism's preservation and progress. ${ }^{103}$ America's advertising stories, its entertainment stories, and its business stories all become its cultural stories-its noble tales for commerce. The aspirational mythmakers aim high, equating capitalism with all of America's most deeply treasured ideals of democracy, liberty, and equality, even though they may know that commerce's practices will sometimes fall low, equating capitalism with individual disenfranchisement, oppression, and inequality. By the mythmakers' efforts, then, many might strive for self-realization through commercial reward.

The regulatory functions of marketplace myths are no less important, albeit much less venerable. Capitalism's very survival requires that it commodify the substance and style of any serious dissent, thereby rendering that dissent both powerless and profitable. ${ }^{104}$ As free speech theorists Ronald Collins and David Skover observe:

Young and old alike are invited to reveal their rebel stripes by donning a James Dean, John Wesley Harding, or Axl Rose T-shirt. For the more radical, Malcolm X baseball caps are commercially available. Rappers, punks, and Mapplethorpe types all may, to

102. In the distinct, though related, context of freedom of speech in the mass media entertainment culture, First Amendment theorists Ronald Collins and David Skover identified the aspirational and regulatory functions of commercial mythmaking. ColLINS \& SKOVER, supra note 83, at 205-10.

103. One of the most important tracts on the function of marketplace mythmaking (spun largely through commercial advertising) to preserve and promote the modern American capitalist system is Jules Henry, Culture Against Man (1963). Presenting his general thesis, Henry declares, "II]n America, as elsewhere in industrialized cultures, it is only the deliberate creation of needs that permits the culture to continue. This is the first phase of the psychic revolution of contemporary life." Id. at 19. See generally The Culture of Consumption: Critical Essays in American History 1880-1980 (Richard Wightman Fox \& T.J. Jackson Lears eds., 1983) (examining the consumer culture and the advertising industry that supports it as both power structures and standards for Ameriean life); LEO Bogart, Commercial Culture: The Media System and the Public Interest 203-17 (I995) (discussing the role of dramatic fiction in journalism that is produced to meet the demands of the market).

104. COLlins \& SKOVER, supra note 83, at 115-16. 
paraphrase Shakespeare, strut and fret their hour upon the stage of pop life and then be seen and heard no more. ${ }^{105}$

Counterculture thus becomes one of commerce's prime commodities. By the mythmakers' efforts, then, many might "radicalize" themselves for conspicuous consumption.

Whether for its aspirational or regulatory purposes, mythmaking plays a definitive role in the commercialization of LesBiGay identity, too. The marketplace manifests that LesBiGay identity may be as desirable as any other commodity. In fact, it may be more desirable because it has a unique exchange value. Commercial culture critic Alexandra Chasin puts it succinctly: LesBiGay "coming-out stories now appear as plots, [their] styles as the styles, [their] stuff as the stuff to buy." 106 Aspirationally, the marketplace promises LesBiGays that their commodified identity will stretch the cultural canvas in creative and compelling ways, that they will get to push the parameters for the commercial culture. Not only will LesBiGays transform the culture, the myth goes, but they will also consume it as fully in/vested American citizens. By the mythmakers' efforts, then, the LesBiGay path to political enfranchisement and social acceptance is paved by consumer sovereiguty.

In its regulatory operations, the marketplace myth is just as confining for LesBiGays as for American society in general, and perhaps with more worrisome effects. Commercialization pulls LesBiGays back from the fringe and into the mainstream, wrenching out of them any real potential for social transformation. Writing in New York magazine in 1996, Daniel Mendelsohn asserted that "the heterosexualization of gay culture" is the most astounding assimilationist phenomenon of our time. ${ }^{107}$ Commodification of their identities renders LesBiGays less powerful as a countercultural force, and simultaneously inore profitable as a cultural force. Queer Nation's cri de coeur, "We're here, we're queer, get used to it," might once have had social revolutionary purpose, but the regulatory mythmakers ensure that it will be no more than another commercial jingle, singing "We're here, we're just like you, don't worry about it."108 Through such cultural appropriation, the mythmakers thus control and limit the possible scope of identity LesBiGays can invent for themselves.

In sonie circles, myths have been harshly criticized. They are condemned as diversionary, escapist, fetishistic, fantastical, and ultimately,

105. Id.; see also Thomas Frank, Why Johnny Can't Dissent, in CoMmodify YouR Dissent 31-45 (Thomas Frank \& Matt Weiland eds., 1997). As Frank puts it tellingly: "Our businessmen imagine themselves rebels, and our rebels sound more and more like ideologists of business." Id. at 41.

106. Chasin, supra note 41 , at 238.

107. Daniel Mendelsohn, When Did Gays Get So Straight?: How Queer Culture Lost Its Edge, New YorK, Sept. 30, 1996, at 26.

108. See Gluckman \& Reed, supra note 43 , at $519,524$. 
false ${ }^{109}$ For the increasingly postmodern American commercial mythmakers, however, angst over matters of truth and falsity is simply beside the point. To the extent that LesBiGays adopt this postmodern stance, perhaps the most significant inquiry might be whether the marketplace myths of LesBiGay identity are useful.

On the one hand, LesBiGays may hope that their mythical identities as affectionate, funny, caring, dynamic, classy, or witty characters to be loved, admired, or envied might blossom into something more in their lived experiences. Conceivably, "average Americans" consuming these images might relate that je ne sais quoi quality of the LesBiGay identity to something within themselves and gradually grow to greater tolerance and acceptance of LesBiGays at the personal, interpersonal, and societal levels. And if feminists and postmodernists are right about the personal being political, these developments might translate to equal regard and treatment in political and legal spheres.

Or maybe not.

Then, on the other hand, mythmaking may not be merely the first inning in a larger sociopolitical ballgame, but the entire ballgame. Even if fantasy is an end unto itself, it may still have salutary utility for LesBiGays. Left with no more than the anger, frustration, and passive victimhood that come from a lack of effective sociopolitical power, the seductive surreality of an R.S.V.P. or Olivia cruise may be all the more necessary. Can the LesBiGay psyche endure a stark and straightforward existence, stripped of all mythical promises, however unattainable they may be? ${ }^{110}$ Philosopher David Nyberg appreciates the practicality of selfdeception, and he forcefully surmises, "We deceive ... so that we might not perish of the truth." 111 As the self-delusive gay prisoner Molina discovered in The Kiss of the Spider Woman, ${ }^{112}$ a retreat into the dreamworld of

109. See generally HeNRY, supra note 103; IAN I. Mitroff \& WARREN BENNIS, THE UNREALITY Industry: The Deliberate Manufacturing of Falsehood and What It Is Doing to OUR Lives (1989) (portraying the deliberate creation of unreality by American mass communication and entertainment media). See also William Leiss et al., Social CoMmunication in Advertising: Persons, Products, and IMAGes of Well-Being 319-27 (1990) (arguing that through marketing and advertising, goods are fitted with "masks" that become our fetishes); BoGART, supra note 103, at 203 ("The commercial culture we absorb in such massive doses envelops us in make-believe and distracts us from the realities of current history that urgently demand our attention.").

110. At a higher level of abstraction, such an inquiry seemed to be of interest to Dr. Sigmund Freud, who considered it "a debatable point whether a certain degree of cultural hypocrisy is not indispensable for the maintenance of civilization." Sigmund Freud, Thoughts for the Times on War and Death, in 14 The Standard Edition of The Complete Psychological Works of Sigmund Freud 275, 284-85 (1957). Within the context of LesBiGay identity, however, commercial mythmaking may well be useful more for its survival force than for its civilizing force.

111. David Nyberg, The Varnished Truth: Truth Telling and Deceiving in Ordinary LIFE 2 (1993).

112. Manuel Puig, The Kiss of the Spider Woman (Thomas Colchie trans., Vintage Books, 1991). 
cinema with his diva heroine Aurora proved, in the end, to be far more lifesustaining than his fatal foray into politics.

\section{III}

\section{Driving BY THE REARVIEW MirRoR}

Marshall McLuhan, Toronto's electrifying communications theorist, detected that society typically drives into the future with its eyes on the "rearview mirror."113 Although McLuhan was writing about society's failure to perceive cultural changes fostered by technological advancements, he might as well have been writing about the legal academy's myopia toward the cultural changes produced by LesBiGay identity's commodification. Surprisingly, in the face of mounting evidence that today's LesBiGays are gaining much in the commercial marketplace, today's legal scholars look primarily to the realms of law and politics where LesBiGays are losing much. Despite the heightened visibility and deepened validation that LesBiGays enjoy in advertising, entertainment, private business, and other economic ventures, law professors engross themselves in arenas that render LesBiGays either invisible or illegitimate. Commerce invites the LesBiGay academy to move forward by looking ahead, but until now it has not shifted its gaze away from the rearview mirror. ${ }^{114}$

McLuhan's indictınent may include LesBiGay scholars generally, yet it must point to its suspects for disparate reasons. These scholars typically focus on the state as the vehicle for LesBiGay advancement, but the vehicle is not the same make, model, or horsepower for all of them, and does

113. Marshall Mcluhan \& Quentin Fiore, War and Peace in the Global Village 18 (McGraw-Hill 1968). According to McLuhan's biographer, the celebrated communications theorist frequently employed the

metaphor he had devised to express what Wyndham Lewis had once taught him: "The present cannot be revealed to people until it has become yesterday." McLuhan termed this the "rearview mirror phenomenon." People went through life looking into the rearview mirror-seeing the present in terms of the past-instead of paying attention to the reality confronting them.

Phimip Marchand, Marshall Mcluhan: The Medium and THe Messenger 209 (1989) (footnote omitted).

114. To their credit, Professors Nancy Levit and Ruthann Robson have glimpsed the key connection between LesBiGay equality and the LesBiGay commodified identity, although neither has explored this profound relationship to any significant extent. See Nancy Levit, $A$ Different Kind of Sameness: Beyond Formal Equality and Antisubordination Strategies in Gay Legal Theory, 61 OHо ST. L. J. 867 (2000); Ruthann Robson, To Market, To Market: Considering Class in the Context of Lesbian Legal Theories and Reforms, 5 S. CAL. Rev. L. \& Women's Stud. 173 (1995). For an unusually creative article proposing that intimate relationships be analyzed as business models, see Martha M. Ertman, Marriage as a Trade: Bridging the Private/Private Distinction, 36 HARv. C.R.C.L. L. REv. 79 (2001).

Any jurisprudential movement progresses, of course, in stages of illumination. Thus, LesBiGay legal scholars have made courageous and foundational contributions to the theories and practices of sociopolitical equality for LesBiGays. The text's critiques of the LesBiGay legal academy do not detract from these worthy efforts. Rather, this Essay encourages those able scholars to train their gaze on the commodified LesBiGay identity that heretofore has been underappreciated. 
not carry them over the same routes. Generally, these scholars fall into two groups, labeled here as the "conventionalists" and the "queerfolk." To a degree, the groups are similar in that they both persist in seeking LesBiGay recognition and valorization through politics and law. The two groups differ, however, in their worldviews, normative agendas, and operational methods. Thus, their relationship (or lack of it) to the LesBiGay commodified identity must be distinguished.

The conventionalists hold that liberty and equality for LesBiGays derive from the traditional rights of political citizenship. Trusting in a Western philosophy of civic participation for the common good that dates back as far as Plato and Aristotle, these legal scholars strive to encompass LesBiGays within the circle of effective political power. Civil libertarians such as William Eskridge and Nan Hunter aim to add sexual orientation as a trait for affirmative legal protection, much as race, religion, and gender are treated. ${ }^{I 15}$ Taking this conventionalist stance, Eskridge characteristically declares, "[T]he laws we seek will enlist the state as an ally in our struggle against social oppression and... will intrude upon private decisionmaking." 116

Similarly, more conservative assimilationists such as Andrew Sullivan and Bruce Bawer insist on strict governmental neutrality toward sexual orientation so that LesBiGays may enjoy equal rights in the public sphere and the liberty of personal choices in the private sphere. ${ }^{117}$

Sullivan synthesizes this narrower conventionalist position by explaining that:

This politics affirms a simple and limited principle: that all public (as opposed to private) discrimination against homosexuals be ended and that every right and responsibility that heterosexuals enjoy as public citizens be extended to those who grow up and find themselves emotionally different. And that is all. ${ }^{118}$

Whether liberal or libertarian, then, the conventionalists embrace the Madisonian worldview of a civic republican democracy, espouse the

115. See William N. Eskridge, Jr. \& Nan D. Hunter, Sexuality, Gender, and the Law (1997); William N. Eskridge, JR., Gaylaw: Challenging the Apartheid of the Closet (1999); Nan D. Hunter et al., The Rights of Lesbians and Gay Men: The Basic aClu Guide to a GAY PERSON's RIGHTS (1992).

116. William N. Eskridge, Jr., A Social Constructionist Critique of Posner's Sex and Reason: Steps Toward a Gaylegal Agenda, 102 YALE L.J. 333, 384 (1992) (reviewing Richard A. POSNER, SEX AND REASON (1992)).

117. See generally ANDREW Sullivan, VirTually Normal: AN ARgument About Homosexuality (1995); Bruce Bawer, A Place at the Table: The Gay Individual in American Society (1993); Beyond Queer: Challenging Gay Left OrThodoxy (Bruce Bawer ed., 1996) (featuring articles by conservative assimilationists, including Sullivan and Bawer).

118. ANDREW Sullivan, supra note 117, at 171; see also Howard Kurtz, The Comeback Columnist: Andrew Sullivan Continues to Defy All Expectations, WASH. Post, Apr. 19, 2001, at C1 (describing Andrew Sullivan as a "gay neo-con," who enjoys "[g]ood public spats" over liberal political issues and delights in being "the victim of demonization by the left"). 
normative objective of incorporating LesBiGays into the existing social order, and endorse an approach of formal equality that adopts the American White heterosexual as the baseline for comparison.

In contrast, the queerfolk scholars hold that liberty and equality for LesBiGays will derive only from "anti-subordinationist" struggles in politics and law. Distrusting the conventional faiths of liberal legal theory and assimilationist politics, and emerging from the contemporary tenets of critical race theory, postmodernisin, and queer theory, the queerfolk mount an intersectional critique against sociopolitical oppression of all minorities (whether based on race, gender, class, or sexuality). Led by such legal scholars as Frank Valdes and Urvashi Vaid, ${ }^{119}$ they advocate a paradigm shift in the LesBiGay rights movement. They seek a turning away from civil rights legislation and litigation and a turning toward coalition-oriented and progressive cultural transformation. Concisely describing the queerfolk's modus operandi, Vaid writes:

The paradigm shift liberation requires is from the political to the cultural. Rather than rejecting the ghetto, our subculture, or queer forms of expression, thought, and art as byproducts of our victimization, we should see them as keys to our freedom. These queer cultural tributaries embody the threat we pose to the heterosexual order. ${ }^{120}$

The queerfolk turn the tables on the assimilationist goals of the conventionalists. Vaid further explains: "That gay people are so universally regarded as a threat to be harshly suppressed suggests that gay and lesbian culture contains ideas that are deeply transformational-and, I believe, redemptive - to the political, moral, and social order now in place."121 At their core, then, the queerfolk embrace a multidimensional worldview of

119. See Francisco Valdes, Queers, Sissies, Dykes, and Tomboys: Deconstructing the Conflation of 'Sex,' 'Gender,' and 'Sexual Orientation' in Euro-American Law and Society, 83 Calif. L. Rev. 1 (1995); Urvashi Vaid, Virtual Equality: The Mainstreaming of Gay \& Lesbian Liberation (1995); see also Darren Lenard Hutchinson, Out Yet Unseen: A Racial Critique of Gay and Lesbian Legal Theory and Political Discourse, 29 ConN. L. Rev. 561 (1997); Katherine M. Franke, The Central Mistake of Sex Discrimination Law: The Disaggregation of Sex from Gender, 144 U. PA. L. Rev. 1 (1995).

120. VAID, supra note 119 , at 180.

121. Id. Francisco Valdes characterizes the queerfolk's intersectional methodology of analysis, observing:

By showing how different forms of bias travel together and combine in social operation, multidimensional analysis may begin to unite multiply diverse outgroups and persuade skeptics that all forms of discrimination based on essentialized identification are wrong for the same reason: they subvert the national commitment to equality, liberty and justice, spreading instead human suffering, as well as social dysfunction and disharmony. 
interconnected systems of oppression, espouse the normative objective of cultural transformation and human liberation, and endorse an approach of substantive equality that adopts Queerness writ large as a basis for celebrating difference.

When it comes to commerce, however, the conventionalists and queerfolk are two sides of the same coin. Obviously, one might infer from conventionalist commitments that whatever economic rights against the state heterosexuals enjoy would transfer to LesBiGays. Similarly, one might infer from queerfolk visions that the totalizing cultural transformation they seek could have dramatic economic ramifications. What is undeniable, though, is that the commercial marketplace is not put front-andcenter by either the conventionalists or queerfolk. And, for momentous reasons, this omission is both unfortunate and ironic.

Were the conventionalists to account for the commodified LesBiGay identity, those scholars would recognize that LesBiGay "self-actualization" within the American commercial system augments the group's social valorization and participatory rights as citizen-consumers. By striving to win in the economic race, LesBiGays are increasingly liberated at the localized level of commerce, despite being continuously restricted at the state and national levels of government. And, by playing to succeed in the inage game, LesBiGays are increasingly celebrated within the mythmaking machines of the commercial entertainment culture, despite being continuously censured within the policymaking mechanisms of the political and legal culture. In effect, then, the commercially conscious conventionalists might witness something approaching their assimilationist goals, but by market operations either nnacknowledged or underappreciated heretofore.

In this regard, it may be ironic that the conservative or libertarian assimilationists, who have long been both the black sheep among other conventionalists and opponents of the LesBiGay Left, ultimately may achieve their objective of same-sex integration, but largely by means that they only implicitly endorse: devotion to the glories of the private commercial marketplace. As far as the enterprise of LesBiGay liberty and equality is concerned, the commercial lesson for the conventionalists is that the modern commodification culture may drive past the law.

Were the queerfolk to account for the commodified LesBiGay identity, they would acknowledge that however revolutionary queer identity once might have been, it has become increasingly reconfigured as conformist by capitalist entrepreneurial striving. Furthermore, however outlier the LesBiGay identity was in the past, it has become increasingly reconstituted as "normal" by the fetishized fantasies and the mainstreaming myths of the commercial system. All this may point to the emergence of economic class, market power, and commercialized lifestyle as the hallmarks of difference throughout society, rather than queer versus straight 
sexuality. Moreover, LesBiGays would be assimilated within their respective classes and market sectors in common with heterosexuals. Again, ironically, it is the queerfolk who have introduced class into their intersectional analysis of subordination and who, yet, may not have understood completely how queerness could be co-opted and sold as still another commodity. As far as the cultural project of transformation and liberation is concerned, the commercial lesson for the queerfolk is that, to escape assimilation, they may have to drive faster and faster at the margins, becoining "queerer" than queer.

With such basic and critical driving lessons as these, it may take a pit crew of psychotherapists to diagnose why the legal academy has had a blind spot to the commodification of LesBiGay identity. Venturing into pop psychology, perhaps, one can speculate briefiy on a few possible mindsets that might have led to oversight.

First, law professors are law professors; the law is what they know how to do, and many of them would like to keep doing it. They know how to extrapolate from race and gender praxis to same-sex praxis when both are, by and large, market-free. But dabbling in unfamiliar or "unprecedential" marketplace myths might impose unanticipated risks, or even threaten them with obsolescence. Moreover, much of LesBiGay civil rights litigation historically took a defensive or reactive posture, which encouraged theorists and practitioners to rely on existing legal analyses rather than to venture into new and forward-looking frameworks. ${ }^{122}$

Second, many law students (from which soine law professors eventually come) may profess an ignorance or fear of mathematics, statistical analysis, quantitative research, and other market matters. To them, coinmercial discourse of any character might be frightening as the mere overture to deeper forays into finance. Third, in a related sense, law is lofty, whereas commerce is crass, or at least that is the aphorism that lawyers may espouse. For them, the dignity and respect attaching to human liberty

122. Obviously, LesBiGay litigants have been well accustomed to acting "on the defeusive," whether literally as criminal defendants asserting constitutional claims against prosecution for sodomy or public indecency or more figuratively as civil rights claimants fighting the uphill battle against political retrenchments of common liberties. A typical litigation strategy in these instances, as in many others, is the attempt to extend already recognized constitutional defenses or affirmative civil rights to relatively "new" LesBiGay contexts. Not surprisingly, such attempts have often failed. See, e.g., Bowers v. Hardwick, 478 U.S. 186 (1986) (declining to extend Fourteenth Amendment substantive due process privacy rights to consensual adult gay sexual relations); Boy Scouts of America v. Dale, 530 U.S. 640 (2000) (declining to extend First Amendment expressive association rights to require the retention of an adult gay scoutmaster); Equality Foundation of Greater Cincinnati, Inc. v. City of Cincinnati, 128 F.3d 289 (6th Cir. 1977) (declining to extend the reasoming of Romer v. Evans to invalidate Cincinnati's charter that prohibited the enactment of LesBiGay antidiscrimination measures), cert. denied, 525 U.S. 943 (1998). 
and equality in the tales of the law should not be debased by stories of the "buying into" and "selling out of" commodified identities. ${ }^{123}$

Fourth, and hardly last, LesBiGay law professors typically share the resistance to societal oppression that generally falls more heavily on their nonprofessional brothers and sisters. Though they may themselves constitute a privileged class, these academics tend to be sensitive to the charges of elitism that may be lodged against them even for conceptualizing LesBiGay struggles in commercial terms. Since the queerfolk, in particular, expanded their LesBiGay studies to include the intersectional concerns of race, ethnicity, gender, and class, they and other LesBiGay scholars might fortify themselves against any market-based analysis that could threaten to obscure their concerns. Because race, ethnicity, and gender track economic class differences so closely, they may fear that any such analysis deeply tied to capitalist exploitation likely will reinscribe these class differences and all of their correlatives.

As a logical proposition, however, it is clear that engaging in market analysis is not synonymous with engaging in capitalist exploitation. The study of a system is not the saine thing as endorsement of that system. Unless or until the revolution comes, ${ }^{124}$ avoiding all talk of the market may well ensure that capitalist exploitation triumphs. Still, at both intellectual and emotional levels, many LesBiGay law professors might feel overwhelming anxiety that the study and the support of commercialism are inseparable.

All told, such mindsets are powerfully fixating. To the extent that the legal academy is captured by those misconceptions, they will block any real awareness of the commercial coding of LesBiGay identity. Those mindsets will prevent a full and unobstructed vision of the commercial routes opened for LesBiGay achievement and progress. Put simply, with their gaze fixated on law and politics, LesBiGay scholars will continue to drive by the rearview mirror.

123. A recent, comprehensive, and commanding work on the commodification of LesBiGay identity is Alexandra Chasin's Selling Out: The Gay and Lesbian Movement Goes to Market, supra note 41 .

124. Some LesBiGay theorists believe that, even if capitalism will never be overthrown, it likely will evolve beyond the early stages of mass production and cultural homogenization to future stages of niche production and cultural heterogeneity. These latter stages entail possibilities for greater social diversity and humane tolerance. See, e.g., Michael Piore, Economic Identity/Sexual Identity, in A QUEER WORLD, supra note 18, at 502, 504-05. 


\section{CONCLUSION \\ A CALl For COMMERCIAL CONSCIOUSNESS}

\section{The question was put to him, \\ What hope is; \\ And his answer was, \\ "The dream of a waking man."}

Aristotle $^{125}$

Aristotle replied to his interlocutor, who sought the path to hope, that the first step on the way is an awakening. Arousing from sleep, the dreamer's reverie is still fresh and tangible. The first moments of consciousness permit a heightened awareness, a pure vision unclouded by the muddle of daily existence.

It is as though the ancient philosopher were addressing modern LesBiGay scholars. Their greater hopes, too, lie in an awakening. Their paths to full LesBiGay liberation also begin with a new step: a heightened awareness of the commodified character of LesBiGay identity and commercialism's impact on LesBiGay self-realization. At the price of ineffectuality, they must answer the call for commercial consciousness.

Those who engage in LesBiGay identity politics must appreciate a dynamic fact: as long as the structures of advanced capitalism remain in place, those structures that drive the modern commercial culture past the law, the emerging LesBiGay consumer identity is likely to overtake and define LesBiGay political and legal identity. LesBiGays are not going to see their images only in the mirror. More tellingly, they are going to see them in the pages of magazines, on the screens of televisions and cinemas, on the stages of theater and music, on the monitors of computers, on the floors of department stores and malls, and throughout the private halls of commerce. These images are ever-changing, as the American commercial culture defines and redefines the commodified LesBiGay identity.

Not only will LesBiGays see their commercialized images, but so will everyone else. Society at large watches the same programs, shops in the same malls, and walks the same commercial halls. Thus, the general populace looks at the LesBiGay identity as mediated by popular culture, and interprets it for what LesBiGays "really" are. Since LesBiGays are not the majority of the populace and must appeal to the majority for its tolerance or acceptance, they must account for their commercially constructed identity. The demeanor may be suave or swishy; the attitude may be butch or bitchy; the character may be lovable or loathsome. Whatever the

125. Attributed to Aristotle in Diogenes Laertius, Lives of Eminent Philosophers, 5:18 (circa A.D. 200). 
attributes, and however positive or negative the images, they must be dealt with by the LesBiGay community and scholars. Though LesBiGays can struggle to resist or reform their commodified identity, they cannot naively pretend that it is not there or merely insist that it is not "them."

This sociology lesson teaches much about why and how the LesBiGay commodified identity functions in the realms of law and politics. America's commercial culture moves far too fast for America's legal and political systems to control it. ${ }^{126}$ The commodified LesBiGay identity plays like an endless movie as the backdrop for legal and political decisionmaking. When judges look up from their opinions and orders, when legislators look up from their committee reports and floor resolutions, and when administrative agency officials look up from their rules and regulations, whether they are friend or foe to LesBiGays they are going to see isolated frames of that movie. How, then, could LesBiGay academics or activists expect to do anything less? How could they hope to influence the political or legal processes affecting LesBiGay interests without focusing on their commodified identity in those same frames? In short, LesBiGays must negotiate their law and politics through that projected image. ${ }^{127}$

126. On an intricately related point, the American commercial culture has taken the helm in reconstituting the American political and legal notions of discourse. 1s it possible today to imagine an American system of free speech that treats commercial advertising as less valuable or less constitutionally protected than political speechmaking? Certainly, the U.S. Supreme Court doesn't think so. See generally Collins \& SKOVER, supra note 83, at 67-135 (asserting that, in our culture of advanced capitalism, there is a striking redundancy in the notion of "commercial speech").

127. "A Call to Consciousness" is not a "Toward a Theory of...." Thus, it is not the purpose of this Essay to provide a full-fledged new legal theory turning on commodified LesBiGay identity. Understanding the commercialization of that identity prompts us (and, hopefully, others) to ask: How could legal scholars take account of LesBiGay commodification in ways that previous legal theories failed to do? What points of resistance, if any, might be available to those who despair of that commodified identity? Even more startling, are the contributions of any legal theorist likely to be nothing but "rearview mirror," in the sense that the forces of commerce might margimalize or entirely subsume them? In short, will the LesBiGay legal academy join the LesBiGay Committee of the American Historical Association?

Those questions remain to be answered primarily because the concept of LesBiGay identity as commodity barely has been recognized, much less analyzed or effectively engaged by such theorists. When they do, however, they might well investigate the following non-exhaustive list of additional questions: How can the LesBiGay targets of commercial exploitation seize agency? How can they control their own commercial images? How might they increase their own market power and learn to deploy it in self-actualizing ways? What are the roles of LesBiGay communities in building market structures and exploiting them to their own ends? And, in all of this, what are the roles and functions of law? Will a commodified path to liberation advantage some LesBiGays above others? If so, is the disparity different either in kind or degree from that pre-existing the recent commercial exploitation of LesBiGay identity? In any case, is that disparity normatively acceptable? And, if not, what could or should the law do about it? Are there marketplace messages to be drawn from, or linkages to be made with, other subordinated groups here and abroad whose identities have been commodified? How might those messages be creatively reshaped for the medium of LesBiGay culture? What are the purposes and practices of law in that reshaping?

In all of this, and from almost all perspectives, there is likely to be something lost and something gained. What that something is, whether law has a signiflcant role in determining the calculus, and ultimately why LesBiGays might be worse off or better off, cannot yet begin to be resolved. 
The commodification of LesBiGay identity and the commercialized culture that forms it and is transformed by it are insufficiently refiected in the work of contemporary LesBiGay legal scholars. Those scholars need not revile or revel in advanced capitalism; they need not condemn or cherish the commercial coding of popular culture; they need not expel or einbrace the commodified LesBiGay identity. But to be effective in law and politics, they need to acknowledge and to account for it.

Centuries after Aristotle's call to consciousness, another eminent political philosopher, the Renaissance Florentine Niccolò Macchiavelli, expressed his love of country by calling for a realpolitik. He considered it "more fitting to go directly to the effectual truth of the thing than to the imagination of it."128 As Machiavelli's pragmatism imstructs today's LesBiGay scholars, it may be more fitting to face the "realities" of capitalism's commodification of LesBiGay identity than to ignore them. And only when conscious of these stark "realities" can they be newly awakened to action. Indeed, the fate of LesBiGays in America may be in need of this Machiavellian brand of love.

128. Niccolò Macchiaveldi, The Prince 61 (Harvey Mansfield, Jr. trans., Univ. of Chicago Press 1985). 
